\title{
PENGARUH DIGITAL MARKETING, PROFITABILITY, LITERASI KEUANGAN, DAN PENDAPATAN TERHADAP KEPUTUSAN INVESTASI LAT (LOBSTER AIR TAWAR) DI INDONESIA
}

\author{
Siti Muhimatul Khoiroh ${ }^{1}$, Siti Mundari ${ }^{2}$, Roikan Sofianto $^{3}$, Ajeng Septiana ${ }^{4}$ \\ Teknik Industri, Fakultas Teknik \\ Universitas 17 Agustus 1945 Surabaya, Surabaya \\ e-mail: ${ }^{1}$ siti_muhimatul@untag-sby.ac.id, ${ }^{2}$ mundari@untag-sby.ac.id, ${ }^{3}$ roykaniwak@gmail.com, \\ 4ajengseptianaagami@gmail.com \\ Diterima: 28 September 2019. Disetujui : 19 Nopember 2019. Dipublikasikan : 30 Desember 2019

\section{ABSTRAK}

Budidaya Lobster Air Tawar (LAT) merupakan komoditi baru dalam bisnis komoditi perikanan hias maupun konsumsi. Lobster jenis redclaw (Cherax quadricarinatus) merupakan jenis bisnis investasi yang tumbuh semakin pesat di Indonesia sejak munculnya Permen Kelautan dan Perikanan No.56/PermenKP/2016. Tingginya permintaan yang tidak diimbangi dengan ketersediaan supply lobster air tawar jenis redclaw yang dikenal mudah dan cepat menyebabkan lambatnya perkembangan pegiat loster dibandingkan dengan besarnya pangsa pasar baik dalam maupun luar negri. Oleh karena itu diperlukan strategi, langkahlangkah serta analisis terkait faktor-faktor apa yang menjadikan minat masyarakat dalam pengambilan keputusan investasi bidang budidaya LAT. Pembuatan model analisis faktor melibatkan faktor digital marketing, literasi keuangan, pendapatan, serta profitabilitas, dan keputusan investasi beserta indikatorindikator variabel dalam sebuah model analisis SEM menggunakan CFA (Confirmatory Factor Analysis). Hasil penelitian menunjukkan bahwa faktor profitabilitas atau tingkat keuntungan yang akan diperoleh dengan nilai loading factor sebesar 0,74 dengan indikator utama yaitu rasio pengembalian modal (P1) sebesar 1,00 .

Kata kunci: digital marketing, keputusan investasi, literasi keuangan lobster air tawar, personal income, profitabilitas

\section{PENDAHULUAN}

Cara Budidaya Lobster Air Tawar (LAT) sebagai bentuk peluang investasi baru di Indonesia merupakan hal baru yang semakin diminati oleh pegiat usaha komoditi Lobster baik untuk hiasan maupun kegiatan konsumtif sejak diterbitkannya Peraturan Menteri Kelautan dan Perikanan No.56/Permen-KP/2016 yang melarang kegiatan penangkapan dan atau pengeluaran lobster, kepiting, dan rajungan dari Indonesia.

Namun terdapat beberapa jenis lobster yang diijinkan untuk dibudidaya dan dikembangkan dalam kegiatan bisnis di Indonesia salah satunya adalah lobster jenis Cherax quadricarinatus (red claw) yang tidak hanya dapat dikonsumsi akan tetapi juga bisa menjadi alternatif akuarium hias.

Peluang investasi budidaya lobster di Indonesia jika dilihat dari Grafik pertumbuhan menurut BPS selama triwulan I tahun 2019 adalah meningkat 0,69\% jika dibandingkan tahun 2018 yang artinya kebutuhan ekspor lobster Indonesia mengalami pertumbuhan $13.03 \%$ per tahun.
Dengan semakin tingginya permintaan dan meluasnya pasar, menumbuhkan trend keputusan investasi di bidang perikanan dan budidaya Lobster. Keputusan investasi berhubungan dengan besarnya dana yang dikeluarkan untuk memperoleh keuntungan jangka panjang yang dapat meningkatkan kekayaan perusahaan (Brealey, Myers, 2009).

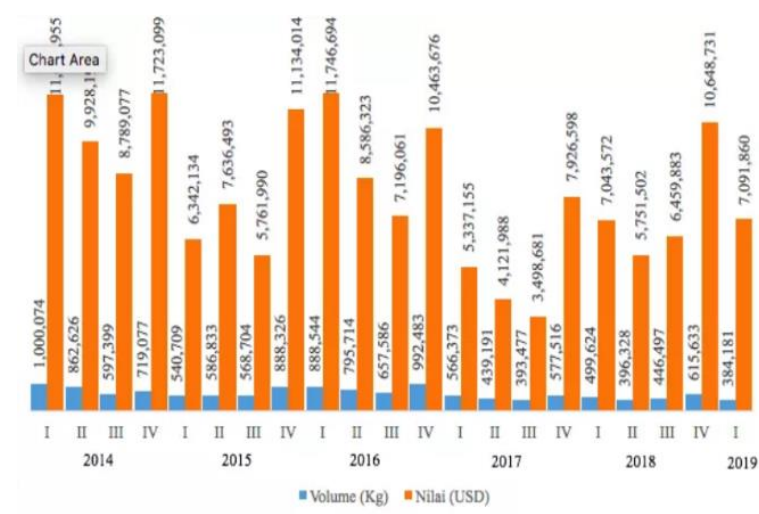

Gambar 1. Perkebamgan Ekspor Lobster Indonesia Tahun 2014-2019 (BPS 2019, Diolah (Suhana, 2019)) 
Perkembangan investasi untuk budidaya LAT jenis redclaw di Indonesia berpeluang besar menjadi komoditi andalan (Kurniasih, 2008). Untuk meningkatkan potensi dan dan peluang tersebut menuju kemandirian ekonomi masyarakat Indoensia sebagai Negara maritime didukung dengan luas wilayah kepulauan, iklim, dan tingginya permintaan masyarakat baik dalam negeri maupun dari luar seperti Taiwan, China, Hongkong, Singapore, Australia, Japan, Malaysia, Korea, hingga United States maka minat investasi masyarakat sebagai pemilik modal secara perorangan maupun organisasi perusahaan perlu menjadi perhatian khusus bagi para pegiat bisnis budidaya LAT.

Trend pola konsumsi protein masyarakat Indonesia sudah beralih dari red meal to white meal harus dianalisis dari aspek finansial dan non finasial. Dari aspek finansial dapat diidentifikasi melalui nilai Net Present Value (NPV), Benefit Cost Ratio (BCR), Internal Rate of Return (IRR). Sedangkan analisis non finansial dapat dilakukan melalui analisis aspek pasar, teknis, manajemen, hokum, ekonomi, serta lingkungan (Afni, 2008).

Pengambilan keputusan investasi oleh seseorang cenderung dilakukan setelah adanya riset terkait beberapa hal yang berhubungan dengan perusahaan, termasuk dalam hal informasi keuangan (Christanti, Natalia., Mahastanti, 2011). Semakin tinggi rasio pengembalian modal/ laba yang didapatkan maka akan memberikan peluang invest yang lebih besar (Ratnasari, 2017). Informasi keuangan dan besar profit yang dihasilkan pada setiap periode menjadi tolok ukur profitabilitas sebuah perusahaan (Christanti, Natalia., Mahastanti, 2011; Endiana, 2017; Ratnasari, 2017).

Selain itu, literasi keuangan juga berkaitan dengan perilaku keuangan (Herawati, 2015). Kemampuan literasi keuangan memerlukan tingkat pengetahuan (knowledge) yang baik, kemampuan dalam memahami angka atau nominal, serta kemampuan memperoleh informasi keuangan (Lopus, Amidjono, \& Grimes, 2019; Septyanto, Dihin., Adhikara, 2013; Skagerlund, Lind, Strömbäck, Tinghög, \& Västfjäll, 2018).

Kemudahan akses informasi juga bergantung sejauh mana informasi yang dapat diakses dan diperoleh dengan mudah oleh calon investor dalam menggali profil dan segala informasi terkait perusahaan secara cepat, tepat, dan ter-update, berinteraksi dengan perusahaan dalam aktivitas bisnis baik secara face to face (offline marketing) maupun melalui e-commerce atau digital marketing (Azmi, 2016).

Selain itu, pengambilan keputusan investasi oleh calon investor akan mempertimbangkan besarnya modal yang harus dikeluarkan atau diinvestasikan guna memperoleh return yang tinggi yang bergantung dari keadaan ekonomi (level pendapatan) personal atau rumah tangga (Malik,
2017). Salah satu budidaya LAT yang berkembang pesat di wilayah Jawa Timur adalah PT. Tri Karya Makmur Jaya (Tama Lobster), dengan sebaran investor yang tersebar diberbagai daerah dan provinsi di Indonesia.

Potensi bisnis budidaya LAT sebagai alternatif pendongkrak perekonomian bidang perikanan dapat membuka lapangan pekerjaan serta dapat meningkatkan level income pembudidaya dan jaringan (chain) bisnis yang terliba. Oleh karena itu, perlu dilakukan analisis terkait faktor-faktor yang menjadi penentu preferensi masyarakat di Indonesia dalam mengambil keputusan investasi agar bisnis budidaya lobster air tawar mampu berkembang secara nasional untuk mendukung perekonomian maritime secara mandiri dengan model on-farm perikanan budidaya yang dibangun dapat memenuhi kebutuhan lokal maupun dunia.

\section{METODE PENELITIAN}

Penelitian ini bertujuan mengembangkan framework model pengambilan keputusan investasi bagi calon investor budidaya lobster yang mengacu pada berbaga hasil penelitian keputusan investasi di berbagai bidang yang berbeda. Tahapan dalam penelitian ini yaitu penentuan kriteria variabel dan indikator penentu keputusan investasi masyarakat di Indonesia, pembuatan model dan hipotesis, penyusunan kuisioner, penentuan jumlah sampel, pengumpulan data, serta pengolahan data dengan aplikasi SEM (Structural Equation Modelling) dengan CFA (Confrmatory Factor Analysis).

Penelitian ini melibatkan responden yang merupakan investor yang merupakan pelaku investasi pada budidaya lobster air tawar yang sudah berjalan dengan mengambil sejumlah sampel bersadarkan rumus Taro Yamane atau Slovin (Rochmah, 2016) :

$$
\begin{aligned}
n & =\frac{N}{N \cdot e^{2}+\mathbf{1}} \\
& =\frac{\mathbf{2 1 7}}{\mathbf{2 1 7} \times \mathbf{0 , 0 5 ^ { 2 } + \mathbf { 1 }}} \\
& =140,680
\end{aligned}
$$

Keterangan :

$n$ : jumlah sampel

$N$ : jumlah populasi

$e$ : margin of error (ditetapkan 5\% dengan tingkat kepercayaan 95\%)

\section{Definisi Operasional Variabel}

1. Digital Marketing

Pemasaran online melalui pemanfaatan ecommerce untuk mempercepat penyampaian informasi terkait dan langkah menarik serta meyakinkan calon investor.

2. Profitabilitas 
Tingkat keuntungan/ kemudahan dalam memperoleh laba yang ditawarkan pada bisnis.

3. Literasi Keuangan

Informasi dan akses transparansi aktivitas operasional, manajemen, maupun keuangan perusahaan kepada calon investor.

4. Pendapatan (personal income)

Adalah tingkat pemasukan yang dimiliki personal atau unit untuk diivestasikan sebagai modal usaha.

Tabel 1. Variabel dan Indikator

\begin{tabular}{|c|c|c|}
\hline Variabel & Kode & Indikator \\
\hline \multirow{3}{*}{$\begin{array}{l}\text { Digital } \\
\text { Marketing } \\
\text { (X1) }\end{array}$} & DM1 & $\begin{array}{l}\text { Kemudahan akses informasi } \\
\text { budidaya LAT }\end{array}$ \\
\hline & DM4 & $\begin{array}{l}\text { Layanan dan fasilitas yang } \\
\text { ditawarkan }\end{array}$ \\
\hline & DM5 & $\begin{array}{l}\text { Tersedianya website, media social, } \\
\text { dan search engine mengenai } \\
\text { budidaya LAT }\end{array}$ \\
\hline \multirow{2}{*}{$\begin{array}{l}\text { Pendapatan/ } \\
\text { Personal } \\
\text { Income (X2) }\end{array}$} & I1 & Pendapatan > beban \\
\hline & $\mathrm{I} 2$ & Preferensi pemanfaatan modal \\
\hline \multirow{2}{*}{$\begin{array}{l}\text { Profitabilitas } \\
\text { (X3) }\end{array}$} & P1 & Rasio pengembalian modal \\
\hline & P2 & $\begin{array}{l}\text { Keuntungan tinggi karena minim } \\
\text { pesaing }\end{array}$ \\
\hline \multirow[t]{3}{*}{$\begin{array}{l}\text { Literasi } \\
\text { Keuangan (X4) }\end{array}$} & $\mathrm{L} 2$ & $\begin{array}{l}\text { Kemampuan memahami angka dan } \\
\text { nominal }\end{array}$ \\
\hline & L3 & Transparansi kegiatan usaha \\
\hline & L4 & $\begin{array}{l}\text { Pemahaman terhadap manfaat } \\
\text { literasi keuangan }\end{array}$ \\
\hline \multirow{4}{*}{$\begin{array}{l}\text { Keputusan } \\
\text { Investasi (Y) }\end{array}$} & KP1 & Investasi untuk profit \\
\hline & KP2 & $\begin{array}{l}\text { Pemilihian investasi dengan } \\
\text { tingkat resiko rendah }\end{array}$ \\
\hline & KI3 & $\begin{array}{l}\text { Pemilihan investasi dengan daya } \\
\text { saing rendah }\end{array}$ \\
\hline & KI6 & $\begin{array}{l}\text { Investasi untuk tabungan jangka } \\
\text { panjang }\end{array}$ \\
\hline
\end{tabular}

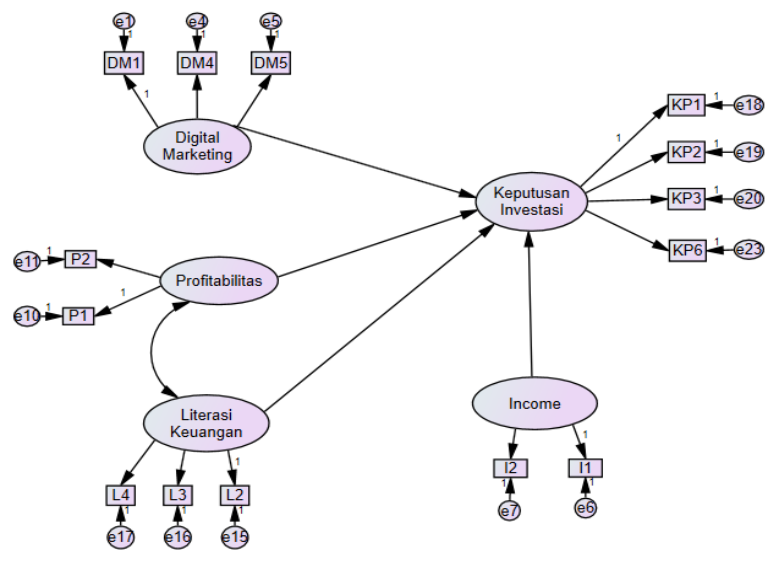

Gambar 1. Model Penelitian

Hipotesa Penelitian :

H1: Digital marketing berpengaruh terhadap keputusan investasi

H2: Pendapatan/ personal income berpengaruh terhadap keputusan investasi

H3: Profitabilitas berpengaruh terhadap keputusan investasi

H4: Literasi keuangan berpengaruh terhadap profitabilitas

H5: Literasi keuangan berpengaruh terhadap keputusan investasi

\section{Analisis Faktor dengan CFA (Confirmatory Factor Analysis)}

Teknik Confirmatory Factor Analysis (CFA) ditujukan untuk mengestimasi measurement. model, menguji undimensionalitas dari konstruk-konstruk eksogen dan endogen. Langkah-langkah CFA (Juniawan, Jefri Eko ; Kusuma, 2017):

1. KMO (Kaiser Meyer Olkin) menunjukkan validitas konstruk dari analisis faktor. KMO minimal 0,5 dan $<0,5$ menunjukkan bahwa analisis faktor tidak dapat digunakan.

2. Measures of Sampling Adequancy (MSA), menunjukkan kelayakan model uji faktor untuk masing-masing variabel dilihat dari MSA. Nilai MSA masing-masing > 0,5 , berarti model layak digunakan dalam analisis faktor.

3. Nilai PCA (Comunalities), pada tahap ini jumlah varian yang diberikan tiap butir dengan butir lain yang dipertimbangkan. Jika Koefisien communality tersebut cukup efektif apabila bernilai 50\%. Apabila terdapat communality kurang dari 50\%, maka harus dipertimbangkan besarnya muatan faktor.

4. Total variance explained menjelaskan kemampuan dari masing-masing faktor menjelaskan variasinya. Jika masing-masing variabel $>60 \%$ mempunyai arti bahwa faktor dari masing-masing variabel memiliki kelayakan untuk menjelaskan variabel faktornya.

5. Loading factor, pada tahap ini loading factor adalah koefisien yang menerangkan tingkat hubungan indikator dengan variabel laten

\section{HASIL DAN PEMBAHASAN}

Dari 150 sampel penelitian yang telah disebarkan questioner, diperoleh informasi terkait profil investor bidang budidaya LAT yang tersebar di Indonesia yaitu :

\section{JENIS KELAMIN}

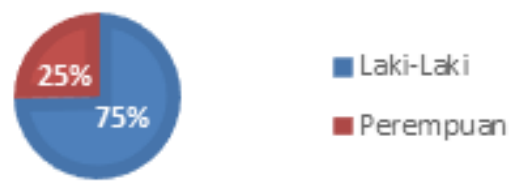

Gambar 2. Gender Investor Budidaya Lobster

Minat investasi lobster air tawar di Indonesia masih didominasi oleh laki-laki jika dibandingkan dengan perempuan sebagaimana pada Gambar 2.

Dalam menjaring kinat investasi, usia memerankan peranan penting untuk pengambilan keputusan sebagaimana pada keputusan investasi bidang LAT yang didominasi oleh investor dengan 
rentang usia produktif yaitu pada kisaran 26 sampai 35 tahun sebagaimana pada Gambar 3.

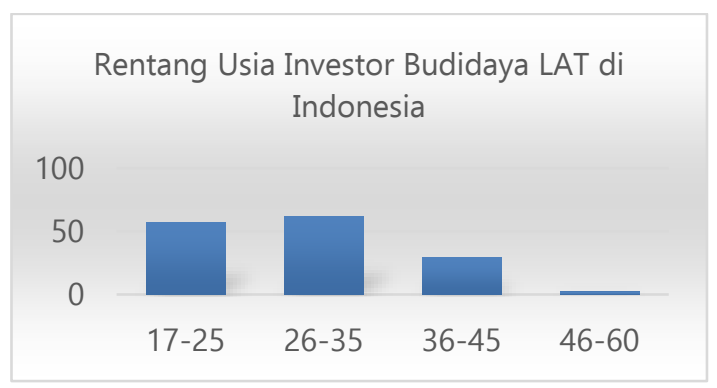

Gambar 3. Sebaran Usia Investor Budidaya LAT

Sedangkan tingkat kesadaran masyarakat akan peluang bisnis lobster air tawar ini dapat dilihat dari sebaran investor yang berasal dari berbagai wilayah yang ada pada sejumlah provinsi yang ada di Indonesia. Jumlah ini akan terus meningkat seiring dengan semakin maraknya kebutuhan dan trend pasar dalam bisnis lobster baik sebagai bahan baku makanan olahan maupun sebagi ikan hias yang semakin banyak diminati masyarakat diberbagai belahan dunia.

Pada Gambar 4, terlihat hasil penelitian menunjukkan sebaran investor pada minat peluang bisnis budidaya lobster tertinggai adalah berasal dari Provinsi Jatim, Jateng, serta Jakarta dan beberapa daerah di Indonesia bagian utara maupun selatan yang lainnya.

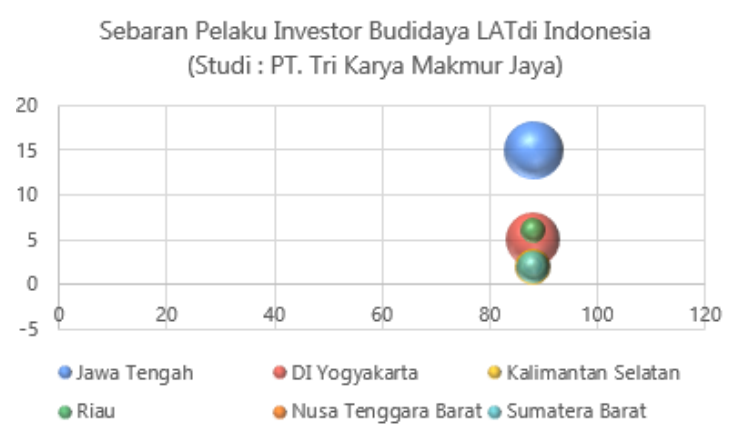

Gambar 4. Sebaran Pelaku Investasi LAT di Indonesia

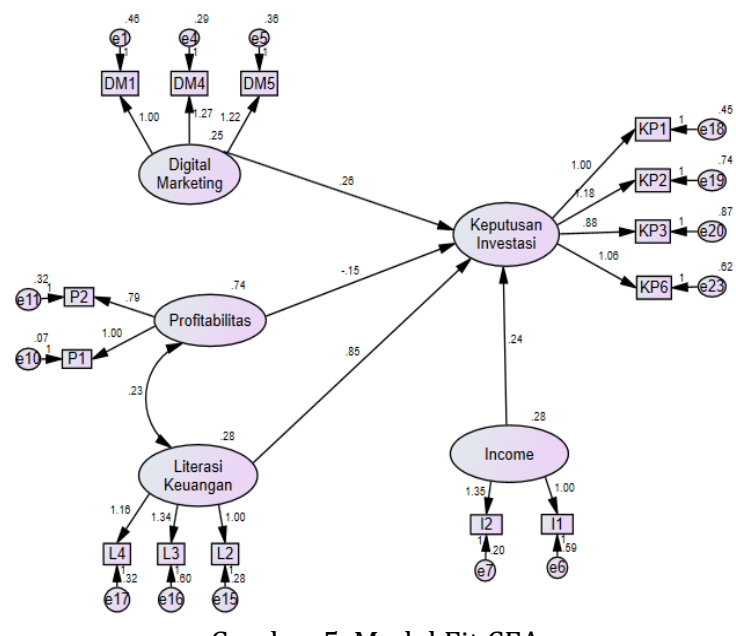

Gambar 5. Model Fit CFA
Kemudian, berdasarkan hasil pengolahan data menggunakan model AMOS dengan pendekatan CFA (Confirmatory Factor Analysis) hasilnya seperti pada Gambar 5.

Berdasarkan Analisis Confirmatory dari faktor-faktor yang diteliti dalam penelitian ini, diperoleh model fit dengan nilai $p$ value $>0,05$.

Tabel 2. Kriteria Hasil Uji CFA

\begin{tabular}{l|l|l}
\hline Goodness of Fit Index & Nilai yang diharapkan & Hasil Uji \\
\hline $\mathrm{X}^{2}$-Chi Square & diharapkan kecil & 86.277 \\
\hline P-value & $\geq 0,05$ & 0.067 \\
\hline RMSEA & $\leq 0.08$ & 0.042 \\
\hline GFI & $\geq 0,9$ & 0.927 \\
\hline TLI & $\geq 0,9$ & 0.965 \\
\hline CFI & $\geq 0,9$ & 0.974 \\
\hline
\end{tabular}

Tabel 2 menunjukkan nilai Chi-Square 86.277 dengan $p$-value 0.067 yang berarti bahwa model fit. Begitu juga dengan kriteria GFI, CFI, TLI nilainya > 0.9 dan RMSEA $0.042<0.08$ maka dapat dikatakan data tersebut valid dan reliabel.

Tabel 3. Assessment of normality

\begin{tabular}{|c|c|c|c|c|c|c|}
\hline Var. & $\min$ & $\max$ & skew & c.r. & kurtosis & c.r. \\
\hline KP6 & 2 & 5 & -1.088 & -4.907 & 0.196 & 0.442 \\
\hline KP3 & 2 & 5 & -0.566 & -2.553 & -1.037 & -2.338 \\
\hline KP2 & 2 & 5 & -0.758 & -3.417 & -0.68 & -1.532 \\
\hline KP1 & 2 & 5 & -1.063 & -4.795 & 0.008 & 0.019 \\
\hline L4 & 2 & 5 & -0.351 & -1.585 & -0.848 & -1.912 \\
\hline L3 & 2 & 5 & -0.334 & -1.507 & -0.726 & -1.636 \\
\hline L2 & 2 & 5 & -0.071 & -0.321 & -0.542 & -1.222 \\
\hline $\mathrm{P} 2$ & 2 & 5 & -0.765 & -3.449 & -0.149 & -0.337 \\
\hline P1 & 2 & 5 & -0.77 & -3.471 & -0.533 & -1.201 \\
\hline $\mathrm{I} 2$ & 2 & 5 & -0.549 & -2.474 & -0.569 & -1.283 \\
\hline I1 & 2 & 5 & 0.029 & 0.13 & -1.174 & -2.648 \\
\hline DM5 & 2 & 5 & -0.689 & -3.107 & -0.19 & -0.428 \\
\hline DM4 & 2 & 5 & -0.588 & -2.652 & -0.244 & -0.549 \\
\hline DM1 & 2 & 5 & -0.198 & -0.892 & -0.629 & -1.419 \\
\hline \multicolumn{5}{|c|}{ Multivariate } & 12.105 & 2.421 \\
\hline
\end{tabular}

Uji normalitas multivariat memberikan nilai critical ratio skenews value $2.421<2.58$ pada Tabel 3 yang berarti secara multivariat data berdistribusi normal dan tidak terdapat outlier pada data.

\begin{tabular}{|c|c|c|c|c|}
\hline \multicolumn{2}{|r|}{ Hubungan } & Estimasi & $\mathrm{P}$-value & Keterangan \\
\hline DM5 & <--- Digital_Marketing & 1.215 & **** & Signifikan \\
\hline I2 & $<--$ Income & 1.353 & 0.031 & Tidak Signifikan \\
\hline $\mathrm{P} 2$ & <--- Profitabilitas & 0.787 & **** & Signifikan \\
\hline L3 & <--- Literasi_Keuangan & 1.343 & ***** & Signifikan \\
\hline L4 & <--- Literasi_Keuangan & 1.157 & ***** & Signifikan \\
\hline KP2 & <--- Keputusan_Investasi & 1.178 & **** & Signifikan \\
\hline KP3 & $<--\quad$ Keputusan_Investasi & 0.877 & **** & Signifikan \\
\hline KP6 & <--- Keputusan_Investasi & 1.064 & **** & Signifikan \\
\hline DM4 & <--. Digital_Marketing & 1.268 & $* * *$ & Signifikan \\
\hline
\end{tabular}

Tabel 4 menunjukkan bahwa terdapat satu indikator yang tidak signifikan yaitu I2, karena indikator mempunyai nilai $p$-value $>0.1$. sedangkan indikator yang signifikan yaitu DM5, P2, L3, L4, KP2, KP3, KP6, dan DM4, karena masing-masing 
indikator mempunyai nilai p-value $<0.1$ dari taraf signifikan.

\begin{tabular}{|c|c|c|c|c|c|}
\hline \multicolumn{2}{|c|}{ Hubungan } & Estimate & S.E. & C.R. & $P$ \\
\hline \multirow{5}{*}{$\begin{array}{l}\text { Keputusan_Investasi < } \\
\text { Keputusan_Investasi }< \\
\text { Keputusan_Investasi < } \\
\text { Keputusan_Investasi < } \\
\text { Profitabilitas }\end{array}$} & \multirow{5}{*}{$\begin{array}{ll}\text { <--- } & \text { Digital_Marketing } \\
\text { <--- } & \text { Profitabilitas } \\
\text { <--- } & \text { Literasi_Keuangan } \\
\text { <--- } & \text { Income } \\
\text { K--> } & \text { Literasi_Keuangan }\end{array}$} & 0.859 & 0.096 & 2.711 & **** \\
\hline & & -0.148 & 0.064 & -2.298 & 0.022 \\
\hline & & 0.847 & 0.158 & 5.355 & $* * *$ \\
\hline & & 0.843 & 0.093 & 2.622 & **** \\
\hline & & 0.23 & 0.052 & 4.404 & $* * *$ \\
\hline
\end{tabular}

Pengujian hipotesis menghasilkan kesimpulan sebagaimana pada Tabel 5, yaitu :

1. H1 Digital marketing berpengaruh signifikan terhadap keputusan investasi.

2. H2 Profitabilitas tidak berpengaruh signifikan terhadap keputusan investasi.

3. H3 Literasi keuangan berpengaruh signifikan terhadap keputusan investasi.

4. H4 Income (pendapatan) berpengaruh signifikan terhadap keputusan investasi.

5. H5 Literasi keuangan berpengaruh signifikan terhadap profitabilitas

\section{PENUTUP}

Keputusan investasi budidaya LAT (Lobster Air Tawar) di Indonesia berdasarkan hasil analisis faktor menggunakan pendekatan CFA (Confirmatory Factor Analysis) diketahui bahwa terdapat indikator yang memiliki nilai loading factor yang mewakili setiap faktor dalam membentuk keputusan investasi. Faktor pertama digital marketing dengan nilai loading factor 0.25 dengan indikator yang mewakili paling tinggi adalah DM4 (loading factor 1.27). Faktor profitabilitas dengan nilai loading faktor 0.74 dan indikator yang mewakili paling tinggi adalah P1 (loading faktor 1.00). Faktor Literasi keuangan dengan nilai loading factor 0.28 dan indikator yang mewakili paling tinggi adalah L3 (loading factor 1.34). Faktor Income dengan nilai loading factor 0.28 dan indikator yang mewakili paling tinggi adalah I2 (loading faktor 1.35). Faktor keputusan investasi dengan nilai loading factor 0.24 dan indikator yang mewakili paling tinggi adalah KP2 (loading faktor 0.87). Dari hasil analisis tersebut dapat diketahui bahwa nilai loading factor yang paling tinggi terhadap keputusan investasi budidaya lobster air tawar di Indonesia adalah faktor profitabilitas.

\section{UCAPAN TERIMA KASIH}

Penelitian ini merupakan luaran dari hibah perguruan tinggi UNTAG Surabaya dan hasil kerjasama dengan PT. Tri Karya Makmur Jaya sebagai objek dalam penelitian. Kami ucapkan terima kasih kepada semua pihak baik LPPM Untag
Surabaya, Pihak Buidaya, para investor, serta pihakpihak yang telah kami libatkan dan yang telah membantu mendukung penelitian ini baik secara moril maupun materiil sehingga dapat menghasilkan luaran berupa artikel ilmiah untuk memperluas cakrawala keilmuan di bidang teknik industri.

\section{DAFTAR PUSTAKA}

Afni, K. (2008). Analisis Kelayakan Pengusahaan Lobster Ait Tawar (Kasus K'BLAST'S Farm, Kec. Gunung Guruh, Kab. Sukabumi, Jawa Barat), 1-104.

Azmi, M. U. (2016). Pengaruh Program Komunikasi pada Digital Marketing dan Sales Promotion Terhadap Impulse Buying Pada Konsumen Situs Lazada.co.id (Survey pada Forum Kaskus).

Brealey, Myers, M. (2009). Dasar-Dasar Manajemen Keuangan (5th ed.). Erlangga.

Christanti, Natalia., Mahastanti, L. A. (2011). FaktorFaktor yang Dipertimbangkan Investor dalam Melakukan Investasi. Jurnal Manajemen Teori Dan Tearapan, 4(3), 37-51.

Endiana, I. D. M. (2017). Analisis Faktor-Faktor yang Berpengaruh Terhadap Keputusan Investasi dengan Grwoth Opportunity sebagai Moderating Variabel. Jurnal Ilmiah Akuntansi Dan Bisnis, 2.

Herawati, N. T. (2015). Kontribusi pembelajaran di perguruan tinggi dan literasi keuangan terhadap perilaku keuangan mahasiswa. Jurnal Pendidikan Dan Pengajaran, 48(1-3), 60-70.

Juniawan, Jefri Eko ; Kusuma, A. A. G. A. E. (2017). Faktor-Faktor yang Mempengaruhi Customer Switching dari Taksi Konvensional ke Taksi Online. E-Jurnal Manajemen Unud, 6(10), 5460-5488.

Kurniasih, T. (2008). Lobster Air Tawar (Parastacidae: Cherax), Aaspek Biologi, Habitat, Penyebaran, dan Potensi Pengembangannya. Media Akuakultur, 3(1), 31-35.

Lopus, J. S., Amidjono, D. S., \& Grimes, P. W. (2019). Improving Financial Literacy of the Poor and Vulnerable in Indonesia: An Empirical Analysis. Biochemical Pharmacology, 100168. https://doi.org/10.1016/j.iree.2019.100168

Malik, A. D. (2017). Analisa Faktpr-Faktor yang Mempengaruhi Minat Masyarakat Berinvestasi di Pasar Modal Syariah Melalui Bursa Galeri Investasi UISI. Jurnal Ekonomi Dan Bisnis Islam, 3(1), 61-84.

Ratnasari, J. T. (2017). Jurnal Analisis Faktor-Faktor yang Mempengaruhi Keputusan Investasi pada Perusahaan Manufaktur Sektor Industri 
Barang yang Terdaftar di BEI.

Rochmah, N. (2016). Pengaruh Soft Skill Staf Perpustakaan Terhadap Pelayanan Prima di Perpustakaan Fakultas Ilmu Sosial dan Ilmu Politik Universitas Gadjah Mada Yogyakarta. Berkala Ilmu Perpustakaan Dan Informasi, XII(2), 144-149.

Septyanto, Dihin., Adhikara, M. F. A. (2013). Perilaku Investor Individu dalam Pengambilan Keputusan Investasi Sekuritas di Bursa Efek Indonesia (BEI).

Skagerlund, K., Lind, T., Strömbäck, C., Tinghög, G., \&
Västfjäll, D. (2018). Financial literacy and the role of numeracy - How individuals' attitude and a ffi nity with numbers in fl uence fi nancial literacy. Journal of Behavioral and Experimental Economics, 74(August 2017), 18-25.

https://doi.org/10.1016/j.socec.2018.03.004

Suhana. (2019). Lobsternomics (2) : Kinerja Ekspor Lobster Triwulan 1 2019. Retrieved from https://suhana.web.id/2019/05/07/lobstern omics-2-kinerja-ekspor-lobster-triwulan-12019/ 